\title{
Transmylohyoid Submental Intubation in complex maxillofacial trauma: The easiest method is also the safest method
}

\author{
Ashutosh Kumar Singh ${ }^{1}$, Sanad Dulal ${ }^{1}$, Rajesh Yadav $^{2}$, Ajay Singh Thapa ${ }^{2}$ \\ ${ }^{1}$ Department of Oral \& Maxillofacial surgery \\ ${ }^{2}$ Department Of Anaesthesiology and critical care \\ College of Medical Sciences, Bharatpur, Nepal
}

\section{Correspondence \\ Dr. Ashutosh Kumar Singh, \\ Department Of Oral \& \\ Maxillofacial surgery, \\ COMS-TH, Bharatpur, Chitwan, \\ Nepal \\ Email: \\ drashutoshkumarsingh@gmail.com}

DOI: http://dx.doi.org/10.3126/ jemsn.v12i1.14455

Article received: March $30^{\text {th }} 2016$ Article accepted: June $30^{\text {th }} 2016$

\begin{abstract}
Background \& Objectives: Complex maxillofacial trauma is a common occurrence with high velocity road traffic accidents. Multiple facial bone fracture with loss of reference point for bony reduction requires use of intra-operative intermaxillary fixation to obtain good occlusion which precludes oral intubation. Fractures of nasal bones and ethmoid bones with complex distorted anatomy lead to inability to perform a nasal intubation. In such cases sub-mental intubation can be a safe and easy method of securing the intra-operative airway thus avoiding tracheotomy and its complications. Materials \& Methods: Retrospective clinical analytical study was planned in which 25 patients were included. Patient's age, sex, type of trauma, time taken for procedure and complications were taken as study variables. Results: Average time taken for the procedure was nine minutes and only four out of 25 cases had complications. Conclusion: Sub-mental intubation requires simple skills, less time and is relatively complication free compared to tracheotomy in securing intra-operative airway during surgeries for complex maxillofacial trauma.

Key words: Airway management; Panfacial fracture; Sub-mental intubation
\end{abstract}

Citation: Singh AK, Dulal S, Yadav R, Thapa AS. Transmylohyoid Submental Intubation in complex maxillofacial trauma: The easiest method is also the safest method. JCMS Nepal. 2016;12(2):55-9.

\section{INTRODUCTION}

Maxillofacial injuries and fractures are nearly always associated with moderate to severe road traffic accidents (RTA). Mandible and zygomaticomaxillary complex are commonest sites of fracture. ${ }^{1}$ About $21.8 \%$ of all the maxillofacial injuries need open reduction and internal fixation. ${ }^{2}$ Pan-facial or maxillofacial injuries may lead to derangement of the architecture and disruption of different components of the upper airway, often with little external evidence of the deformity. In many such situations, neither oral nor nasal route for intubation is appropriate during the surgical repair. Recent advancements in the discipline of oral and maxillofacial surgery and availability of new techniques and technologies have made rigid fixation with mini and microplate osteosynthesis possible in almost all facial fractures. Conventional orotracheal intubation leads to inability to close the occlusion which is a pre requisite to obtain reduction of facial bones especially in complex panfacial trauma where multiple fractures of both upper and lower jaw renders the surgeon dependent on dental occlusion as a reference point for reduction of fractured bones. Nasotracheal intubation may be impossible as deformity or fracture of nasal bones, cribriform plate of ethmoid or naso-orbital ethmoid complex are often associated. Efficacy of topical anesthesia over traumatized and inflamed mucosa is uncertain. Moreover, even a small bleed in presence of altered anatomy may lead to complete loss of vision through a fiberscope and may lead to an emergent situation. Potential complications of nasotracheal intubation are mucosal dissection, injury to adenoids, meningitis, sepsis, sinusitis, epistaxis, dislodgement of bony fragments, and obstruction of the tube by the distorted airway anatomy or rarely intracranial intubation. ${ }^{3}$ In patients requiring simultaneous nasal or nasoorbital ethmoid reconstruction after the rigid fixation of mandible and/or maxilla, intraoperative switching over of the endotracheal tube (ETT) from nasal to oral route is required which may compromise the surgical field sterility and may increase the possibility of pulmonary aspiration. Possible difficulty in airway 
management, disruption of surgical repair, and obstruction to the operative field are additional limitations. ${ }^{4}$

That leaves us with elective short term tracheostomy which is associated with its own set of complications. The procedure is difficult in obese patients, children, and patients with thyroid swelling. ${ }^{5}$ The incidence of immediate complications is six to eight percent and they include haemorrhage, surgical emphysema, pneumothorax, pneumomediastinum, and recurrent laryngeal nerve palsy. The incidence of delayed complications is $60 \%$ and they include stomal and respiratory tract infections, blockage of the tube, dysphagia, difficulty with decannulation, tracheal stenosis, tracheoesophageal fistula, and suboptimal visible scar. ${ }^{6}$ Compared to tracheostomy, submental intubation is associated with lesser postoperative complications and requires minimal postoperative care resulting in shorter duration of hospitalization. This procedure can be carried out even in a set up with limited resources. ${ }^{7}$ Preoperative submental intubation in craniofacial injuries was first proposed by a Spanish faciomaxillary surgeon, Francisco Hernandez Altemir in $1986 .{ }^{8}$ He proposed it as an alternative to short-term elective tracheostomy, where both oral and nasal route for endotracheal intubation were not feasible. It is also used in surgeries where both nasal and oral passages are used by the surgeons (e.g., repair of postcancrum oris defects ${ }^{9}$ oronasal fistula, selected cleft lip, and palate surgeries). Repair of congenital malformations, skull base surgery, multiple or complex facial osteotomies, transfacial oncologic procedures of the cranial base, and pediculated craniofacial surgeries are current indications for submental intubation.

\section{MATERIALS AND METHODS}

This retrospective clinical analytical study of 185 patients of maxillofacial trauma spanning two years (August 2013 to July 2015), at College of Medical Sciences Bharatpur, Nepal was done out of which

Table 1: Distribution of anemic patients according to severity

\begin{tabular}{lll} 
Grading of anemia & Male & Female \\
Grade I & 13 & 3 \\
Grade II & 1 & 3 \\
Grade III & 0 & 2 \\
Grade IV & 1 & 2 \\
\hline
\end{tabular}

25 were intubated with submental intubation. The selection criteria for these patients was panfacial trauma involving nasal and nasoorbitomethoid bones with derangement of occlusion precluding conventional orotracheal or nasal intubation. Fiberoptic instrument was not available. Flexometallic tube was used in all cases. Data related to the type of fractures present in each case, sex, age, type of trauma, time required for the submental intubation procedure and the complications associated to it were considered analysis variables in this study.

\section{Surgical technique:}

Materials:

- Flexometallic tube with a bulb or cuff and a detachable connector.

- Curved haemostatic pinches.

- Sheet no. 15 with the corresponding handle for it.

- 4-0 silk or nylon suture.

Surgical Steps:

1. A standard oroendotracheal intubation was performed after asepsis and antisepsis of the mouth and chin.

2. Subsequently, a $2 \mathrm{~cm}$ skin incision was made in the para- median submental region, adjacent to the lower edge of the mandible.

3. The muscle layers (neck cutaneous muscles and mylohyoid muscles) were removed using a pair of curved haemostatic pinches always in touch with the lingual cortex of the mandible. On the lingual floor mucosa, an intraoral incision was made using the distal end of the pinches as a reference, and the pinches were then opened using the sublingual caruncle as a reference and, as a consequence, a tunnel was created.

4. The tube was passed in 2 steps: the tube cuff was first introduced into the mouth and then it was passed through the tunnel using a clamp. The same manoeuvre was then carried out with the proximal end of the tube after disconnecting it from the breathing system of the anaesthesia machine.

5. Then, the tube was re-connected to the breathing system of the anaesthesia machine. The tube was

Table 2: Correlation between different parameters with hemoglobin level

\begin{tabular}{llll} 
Variables & $\begin{array}{l}\text { Yes (Hb level } \\
\text { gm\%) }\end{array}$ & $\begin{array}{l}\text { No (Hb level } \\
\text { gm\%) }\end{array}$ & $\begin{array}{l}\mathbf{P} \\
\text { value }\end{array}$ \\
\hline ART use & 11.58 & 12.02 & 0.60 \\
\hline Malnutrition & 10.93 & 11.86 & 0.39 \\
$\begin{array}{l}\text { Opportunistic } \\
\text { infections }\end{array}$ & 11.81 & 11.9 & 0.91 \\
\hline
\end{tabular}


placed on the skin in the submental region.

At the end of the surgery, the reversion is performed by replacing the tube and, subsequently, the cuff through the incision made; the tube was re-connected to the anaesthesia machine, and the intubation becomes a classic oral intubation.

\section{RESULTS}

Out of 25 participants 17 (68\%) were males and 18 $(72 \%)$ were females. Age ranged from 9 to 62 with an average of 34.4. Time require to perform the procedure ranged from six to 14 minutes with an average of nine minutes. Complications were seen in four cases. Noticeable scar was noticed in two patients whereas bleeding from floor of mouth and submental hepatoma occurred in a case each. Bleeding from floor of mouth was controlled with homeostatic agents and electrocautery and submental hematoma was managed conservatively with pharmacotherapy without any untoward consequences.

\section{DISCUSSION}

Submental intubation allows unhindered approach to oral and nasal cavity sometimes simultaneously without any untoward complications. The need to do inter maxillary fixation during fracture reduction in panfacial trauma makes submental intubation a safe and easy method of securing the airway. Unavailability of fiberoptic transillumination instruments for intubation also makes it a very useful skill to have. The main purpose of submental intubation is to avoid tracheotomy where oral and nasal intubation cannot be performed. Tracheostomy risks are well documented and include the following: haemorrhage, subcutaneous emphysema, pneumomediastinum, tracheostomy cannula obstruction, tracheitis, cellulite, pulmonary atelectasis, tracheoesophageal fistula, tracheocutaneous fistula, pneumothorax, recurrent laryngeal nerve damage, stomal and respiratory tract infections, tracheal stenosis, tracheal erosions,

Table 1: Grouping of patients according to fracture pattern

$\begin{array}{rlr}\text { Group } & \text { Fracture description } & \text { No } \\ 1 & \text { ZMC (unilateral) with nasal component } & 7 \\ 2 & \text { Bilateral Lefort II with nasal bone fracture } & 8 \\ 3 & \text { Pan-facial fractures } & 7 \\ 4 & \text { NOE type II and III } & 3\end{array}$

Table 2: Variables assessed in the study population

\begin{tabular}{|c|c|c|c|c|c|}
\hline $\begin{array}{l}\text { Case } \\
\text { No }\end{array}$ & Age & Sex & $\begin{array}{l}\text { Fractu } \\
\text { re } \\
\text { Group }\end{array}$ & $\begin{array}{l}\text { Time } \\
\text { requir } \\
\text { ed }\end{array}$ & $\begin{array}{l}\text { Complicati } \\
\text { ons }\end{array}$ \\
\hline 1 & 32 & $M$ & 1 & 7 & None \\
\hline 2 & 27 & $M$ & 4 & 8 & None \\
\hline 3 & 21 & $\mathrm{~F}$ & 4 & 8 & None \\
\hline 4 & 33 & $F$ & 1 & 9 & None \\
\hline 5 & 47 & $\mathrm{M}$ & 1 & 9 & None \\
\hline 6 & 9 & $M$ & 3 & 12 & $\begin{array}{l}\text { Hypertrophi } \\
\text { c scar }\end{array}$ \\
\hline 7 & 55 & $\mathrm{~F}$ & 1 & 6 & None \\
\hline 8 & 43 & $\mathrm{~F}$ & 3 & 6 & None \\
\hline 9 & 27 & $\mathrm{~F}$ & 2 & 12 & None \\
\hline 10 & 11 & $\mathrm{M}$ & 3 & 14 & None \\
\hline 11 & 58 & $\mathrm{M}$ & 1 & 10 & $\begin{array}{l}\text { prolonged } \\
\text { intra-oral } \\
\text { bleeding }\end{array}$ \\
\hline 12 & 32 & $\mathrm{~F}$ & 1 & 10 & None \\
\hline 13 & 33 & $\mathrm{M}$ & 2 & 9 & None \\
\hline 14 & 21 & $\mathrm{M}$ & 2 & 9 & None \\
\hline 15 & 56 & $M$ & 1 & 8 & None \\
\hline 16 & 32 & $\mathrm{M}$ & 3 & 11 & None \\
\hline 17 & 20 & $\mathrm{M}$ & 4 & 12 & None \\
\hline 18 & 21 & $\mathrm{~F}$ & 3 & 14 & $\begin{array}{l}\text { sub-mental } \\
\text { hematoma }\end{array}$ \\
\hline 19 & 27 & $\mathrm{M}$ & 3 & 7 & None \\
\hline 20 & 22 & $\mathrm{M}$ & 2 & 8 & None \\
\hline 21 & 55 & $\mathrm{M}$ & 1 & 11 & None \\
\hline 22 & 62 & $\mathrm{M}$ & 3 & 8 & None \\
\hline 23 & 34 & $\mathrm{~F}$ & 1 & 8 & None \\
\hline 24 & 42 & $\mathrm{M}$ & 1 & 9 & None \\
\hline 25 & 40 & $\mathrm{M}$ & 4 & 7 & $\begin{array}{l}\text { noticeable } \\
\text { scar }\end{array}$ \\
\hline
\end{tabular}


dysphagia, problems with decanulation, excessive scarring, and careful surgical and perioperative handling requirements. ${ }^{10-13}$

The submental intubation does not imply a considerable risk for patients or a significant extension of surgical time. In our case, the minimum time was $6 \mathrm{~min}$ and the maximum time was $14 \mathrm{~min}$, similar to the figures reported in the literature. ${ }^{14-16}$

It is noteworthy and worth mentioning that:

1. The incision and blunt dis- section are made in the paramedian area, in order to avoid the separation or injury of geniohyoid and genioglossus muscles, which are moved towards the middle area. Upon conducting this manoeuvre, the suture may only be performed on the subcutaneous tissue and skin, which enables the rest of the layers to heal by secondary intention.

2. The dissection is performed on the periosteum and not inside the subperiosteal space, as originally described by Hernández Altemir. This is to avoid excessive periosteal section of bone fragments that may already have compromised vascularity. This is based on the fact that periosteal irrigation will not be affected by the approach. The advantages of these modifications are reported in the literature. ${ }^{1,3,10-15}$

3. Though this method is a good option for the securing the airway of patients with multiple fractures in the maxillofacial region, it is not free of complications. The most important complications include damage to the tube bulb, submental injury infection, abscess formation in the floor of the mouth, injury to the submandibular salivary ducts or sub- lingual glands, mucocele formation, injury to the marginal branch of the facial nerve, injury to facial vessels (in some cases), and keloid or hypertrophic scarring in the submental region. We also encountered hypertrophic scarring in two cases which was not a major concern since the incision was small and was placed under shadow of mandible. In one case, we encountered hematoma in submental region presumably due to inadvertent injury to submental vessels. Bleeding from floor of mouth was encountered own one case which was easily controlled. Thus this method remains one of the safest and easiest to secure the airway in complex facial fractures if performed keeping in mind anatomical structures and safeguarding them.

\section{CONCLUSION}

Submental transmylohyoid intubation provides an easy and safe way to secure the airway in complex maxillofacial trauma where intraoperative IMF is required and simultaneous access to oral and nasal cavity is required. It is also adequate and minimally invasive in avoiding tracheotomy in such cases thus providing least complicated recovery to the patients. It also provides safe method of intubation in case of involvement of nasoorbitoethmoid bones and base of skull fractures were nasal intubation is contraindicated with least amount of complications and shortest intraoperative time required to perform.

\section{REFERENCES}

1. Venugopal MG, Singha R, Menon PS, Chattopadhyay PK, Roychowdhury SK. Fractures in the maxillofacial region: A four year retrospective study. Medical Journal Armed Forces India. 2010;66:14-7.DOI: 10.1016/S0377-1237(10) 80084-X

2. Chandra Shekar BR, Reddy CV. A five-year retrospective statistical analysis of maxillofacial injuries in patients admitted and treated at two hospitals of Mysore city. Indian J Dent Res. 2008;19:304-8.DOI: 10.4103/09709290.44532

3. Arrowsmith JE, Robertshaw HJ, Boyd JD. Nasotracheal intubation in the presence of frontobasal skull fracture. Can J Anaesth. 1998;45:71-5. DOI: 10.1007/BF03011998. PMID:9466033.

4. Anwer HM, Zeitoum IM, Shehata EA. Submandibular approach for tracheal intubation in patients with panfacial fractures. Br J Anaesth. 2007;98:835-40. DOI: 10.1093/ bja/aem094. PMID:17459905.

5. Durbin CG., Jr Early complications of tracheostomy. Respir Care. 2005;50:511-5. PMID:15807913.

6. Caron G, Paquin R, Lessard MR, Trepanier CA, Landry PE. Submental endotracheal intubation: An alternative to tracheotomy in patients with midfacial and panfacial fractures. J Trauma Inj Infect Crit Care. 2000;48:235-40. DOI: 10.1097/00005373-200002000-00007.

7. Kar C, Mukherjee S. Submental intubation: An alternative and cost-effective technique for complex maxillofacial surgeries. J Maxillofac Oral Surg. 2010;9:266-9. DOI: 10.1007/s12663-010-0084-x. PMID:22190802.

8. Altemir FH. The submental route for endotracheal intubation: A new technique. J Maxillofac Surg.1986;14:64 -5. DOI: 10.1016/S0301-0503(86)80261-2.

9. Eipe N, Neuhoefer E, Rosee GL, Choudhrie R, Samman N, Kreusch T. Submental intubation for cancrum oris: A case report. Pediatr Anesth. 2005;15:1009-12. DOI:10.1111/ j.1460-9592.2005.01573.x. PMID:16238567.

10. Shenoi R, Badjate S, Budhraja N. Submental orotracheal intubation: our experience and review. Ann Maxillofac Surg. 2011;1:37-41. DOI: 10.4103/2231-0746.83154. PMID:23482892.

11. Lima SM, Asprino L, Moreira RW, de Moraes M. A retrospective analysis of submental intubation in maxillofacial trauma patients. J Oral Maxillofac Surg 2011;69:2001-5. DOI: 10.1016/j.joms.2010.10.017. PMID:21367502.

12. Navaneetham A, Thangaswamy V, Rao N. Submental intubation: our experience. J Maxillofac Oral Surg. 
2010;9:64-7. DOI: 10.1007/s12663-010-0018-7. PMID:23139571.

13. Moggi L, Basigalup O, Ciechomski J, Vanelli A. Intubación transmilohioidea traqueal en cirugías craneomaxilofaciales. Rev Arg Anest. 2001;59:22-6.

14. Maclnnis E, Baig M. A modified submental approach for oral endotracheal intubation. Int J Oral Maxillofac Surg. 1999;28:344-6. DOI: 10.1016/S0901-5027(99)80079-4.

15. Mahmood S, Lello G. Oral endotracheal intubation: median submental (retrogenial) approach. J Oral Maxillofac Surg. 2002;60:473-4. DOI: 10.1053/joms.2002.31244.

PMID:11928115.

16. Faraj J, AlKhalil M, Darwishb A, Faraj I, El-Zenati H, Altraifi Y, et al. Submandibular intubation; our experience in Qatar and a short review of literatura. Egypt J Ear Nose Throat Allied Sci. 2013;14:119-21. DOI:10.1016/ j.ejenta.2013.01.001. 